\title{
DETERMINAN FAKTOR INTERNAL DAN EKSTERNAL TERHADAP NILAI PERUSAHAAN FOOD AND BEVERAGE DI BURSA EFEK INDONESIA
}

\author{
Ameilia Damayanti1, Mira Munira ${ }^{2}$ \\ Program Studi Akuntansi \\ Fakultas Ekonomi dan Bisnis Universitas Pancasila
}

\begin{abstract}
Article history:
Received 8 Mei 2019

Revised 14 Juni 2019

Accepted 17 Juni 2019
\end{abstract}

A R T I C L E I N F O

Key words:

Return On Asset, Debt to Equity Ratio, Inflation

\begin{abstract}
A B S T R A C T
Companies with good financial performance will produce maximum profits so that they have a high return on investment. The purpose of this study is to prove and explain the effect of profitability (ROA), leverage (DER), and inflation partially to PBV of food and beverage companies listed on the Indonesia Stock Exchange (IDX), as well as the effect of profitability (ROA), leverage (DER), and inflation simultaneously to $P B V$ at food and beverage companies listed on the IDX. The data used in the study are secondary data, in the form of audited financial statements of companies listed on the Indonesia Stock Exchange. The study population was 10 food and beverage companies listed on the IDX in 2012 - 2017 with the sampling technique used was purposive sampling. The analysis was carried out with quantitative descriptive analysis techniques using IBM SPSS 21. The results of data analysis showed that partially ROA had a significant effect on $P B V, D E R$ and inflation partially had no significant effect on PBV. Simultaneously ROA, DER, and inflation have a significant influence on the $P B V$ of food and beverage companies listed on the IDX.
\end{abstract}

\begin{abstract}
A B S T R A K
Perusahaan dengan kinerja keuangan yang baik akan menghasilkan laba yang maksimal sehingga memiliki tingkat pengembalian investasi yang tinggi. Tujuan dari penelitian ini adalah untuk membuktikan dan menjelaskan pengaruh profitabilitas $(R O A)$, leverage (DER), dan inflasi secara parsial terhadap PBV perusahaanperusahaan food and beverage di BEI, serta pengaruh profitabilitas (ROA), leverage (DER), dan inflasi secara simultan terhadap PBV pada perusahaan food and beverage yang terdaftar di BEI. Data yang digunakan dalam penelitian adalah data sekunder, berupa data laporan keuangan auditan perusahaan yang terdaftar di Bursa Efek Indonesia. Populasi penelitian adalah 10 perusahaan food and beverage yang terdaftar di Bursa Efek Indonesia (BEI) pada tahun 2012 - 2017 dengan teknik penentuan sampel yang digunakan adalah purposive sampling. Analisis dilakukan dengan teknik analisis deskriptif kuantitatif dengan menggunakan IBM SPSS 21. Hasil analisis data menunjukkan bahwa secara parsial ROA berpengaruh signifikan terhadap $P B V, D E R$ dan inflasi secara parsial tidak berpengaruh signifikan terhadap PBV. Secara simultan ROA, DER, dan inflasi terdapat pengaruh signifikan terhadap PBV perusahaan food and beverage yang terdaftar di BEI.
\end{abstract}

\section{PENDAHULUAN}

Perusahaan adalah suatu organisasi yang mengkombinasikan dan mengorganisasikan berbagai sumber daya dengan tujuan untuk memproduksi barang dan/atau jasa untuk dijual. Menurut theory of the firm, tujuan utama perusahaan adalah untuk memaksimalkan nilai perusahaan (value of the firm) (Salvatore,2005). Perusahaan dengan nilai perusahaan yang baik merupakan perusahaan dengan kinerja keuangan yang baik dan memiliki tingkat pengembalian yang baik pula. Nilai perusahaan sangat penting bagi perusahaan, oleh karena itu perusahaan harus memperhatikan tinggi rendahnya nilai perusahaan.

Nilai perusahaan merupakan persepsi investor terhadap perusahaan, yang sering dikaitkan harga sa-

\footnotetext{
*Corresponding author, email address: 1 amel.damay@univpancasila.ac.id
} 
ham. Harga saham yang tinggi membuat nilai perusahaan juga tinggi. Harga saham merupakan harga yang terjadi pada saat saham diperdagangkan di pasar (Fakhrudin dan Hadianto, 2001). Nilai perusahaan lazim diindikasikan dengan price to book value. Price to book value yang tinggi akan membuat pasar percaya atas prospek perusahaan ke depan. Hal ini juga menjadi keinginan para pemilik perusahaan, sebab nila perusahaan yang tinggi mengindikasikan kemakmuran pemegang saham juga tinggi (Soliha and Taswan, 2002).

Price to book value juga merupakan salah satu rasio pasar yang menjadi indikator kinerja keuangan perusahaan. Robert Ang (2010) mengatakan bahwa kinerja keuangan dapat diukur dengan rasio keuangan, diantaranya adalah rasio pasar (market ratios), yang salah satunya dengan menganalisa rasio PBV atau nilai perusahaan. PBV merupakan salah satu rasio pasar yang dapat digunakan untuk mengukur kinerja harga saham terhadap nilai bukunya. PBV juga menunjukkan seberapa jauh perusahaan mampu menciptakan nilai perusahaan relative terhadap jumlah modal yang diinvestasikan. Semakin tinggi rasio PBV, semakin baik kinerja perusahaan dinilai oleh pemodal dengan dana yang telah ditanamkan di perusahaan. Oleh karena itu dapat disimpulkan semakin tinggi rasio PBV, maka semakin tinggi tingkat kepercayaan pasar terhadap prospek perusahaan, maka akan menjadi daya tarik bagi investor untuk membeli saham tersebut, sehingga permintaan akan naik, kemudian mendorong harga saham naik (Wulandari, 2009).

Faktor-faktor yang mempunyai kecenderungan berpengaruh terhadap nilai perusahaan adalah faktor internal dan eksternal. Dalam penelitian ini, faktor internal di proksikan dengan ROA dan DER, sementara faktor eksternal di proksikan dengan inflation rate. Dalam penelitian ini digunakan data perusahaan sektor food and beverages. Sektor food and beverages di Indonesia sangat menarik untuk dicermati karena perkembangannya mempengaruhi kelancaran aktivitas perekonomian indonesia. Fenomena yang terjadi pada perusahaan food and beverage selama periode penelitian menunjukan kinerja keuangan perusahaan yang fluktuatif, karena dipengaruhi oleh faktor internal dan faktor eksternal. Sementara itu, sampai saat ini perusahaan makanan dan minuman merupakan salah satu sektor usaha yang diminati oleh para investor, alasannya adalah sector ini merupakan salah satu sector yang dapat bertahan dalam apapun kondisi perekonomian Indonesia, dan memiliki prospek kedepan yang sangat baik sehingga sector makanan dan minuman ini dianggap akan terus bertahan. Oleh sebab itu data penelitian yang dipilih adalah data perusahaan sector fod and beverages atau makanan dan minuman.

Salah satu factor internal yang mempengaruhi nilai perusahaan adalah Debt to Equity Ratio (DER). DER merupakan salah satu indikator yang mempengaruhi nilai perusahaan, dalam penelitian ini PBV. Hal ini diperkuat oleh beberapa peneliti yang telah melakukan penelitian terhadap hubungan antara solvabilitas terhadap nilai perusahaan. Anugraha (2013) menganalisis bahwa keputusan pendanaan yang diproksikan dengan DER berpengaruh negatif namun tidak signifikan terhadap PBV pada perusahaan sektor otomotif. Sedangkan Hidayati (2010) dalam penelitiannya pada perusahaan sector manufaktur menunjukan bahwa DER dan DPR, secara parsial berpengaruh negatif dan tidak signifikan terhadap PBV. Sedangkan DER, Deviden Payout, ROE, dan Size secara simultan berpengaruh signifikan terhadap PBV.

Faktor lain yang memiliki kecenderungan berpengaruh terhadap nilai perusahaan adalah tingkat profitabilitas. Noor (2011) menyimpulkan dalam penelitiannya pada perusahaan secktor telekomunikasi, secara parsial TATO dan NPM berpengaruh positif dan signifikan terhadap kinerja keuangan perusahaan. Secara simultan Current Ratio, DER, TATO, dan NPM mempengaruhi kinerja keuangan perusahaan yang diproksikan dengan ROI. Hidayati (2010) dan Anugraha (2013) dalam penelitiannya menyimpulkan bahwa ukuran perusahaan yang diproksikan dengan Total Asset dan ROE secara parsial berpengaruh positif dan signifikan terhadap nilai perusahaan yang diproksikan melalui PBV pada perusahaan sub sektor otomotif dan komponen yang terdaftar di bursa Efek Indonesia periode 2009-2012.

Faktor fundamental lain yang memiliki kecenderungan berpengaruh terhadap Kinerja Keuangan Perusahaan adalah Size (ukuran perusahaan) yang diproksikan dengan Total Asset. Size perusahaan dilihat dari Total Asset yang dimiliki oleh perusahaan yang dapat dipergunakan untuk kegiatan operasi perusahaan. Jika perusahaan memiliki Total Asset yang besar, pihak manajemen lebih leluasa dalam mempergunakan asset yang ada di perusahaan tersebut. (Hidayati, 2010).

Penelitian ini mengisi celah penelitian-penelitian yang terdahulu yang membuat tentang determinasi factor internal dan eksternal perusahaan terhadap nilai perusahaan namun dari objek penelitian dan periode penelitian yang berbeda.

Berdasarkan latar belakang di atas dan dari beberapa hasil penelitian terdahulu yang masih belum konklusif maka penulis tertarik untuk meneliti lebih lanjut faktor internal dan eksternal pada perusahaan 
food and beverage dengan menggunakan profitabilitas yang diukur dengan return on asset, leverage yang diukur dengan debt equity ratio, dan inflasi terhadap nilai perusahaan yang diukur dengan price to book value. Pada beberapa penelitian terdahulu beberapa variabel yang diuji memberikan hasil yang berbeda, dengan asumsi konteks, waktu penelitian dan objek yang diteliti berbeda maka penelitian dapat menghasilkan kesimpulan yang berbeda. Perbedaannya yaitu pada kriteria pengambilan sampel yang berasal dari perusahaan sektor food and beverage, penambahan variabel current ratio dan inflasi serta periode pengamatan tahun 2012-2017.

Berdasarkan uraian tersebut, maka rumusan masalah pada penelitian ini adalah : (1) adakah pengaruh profitabilitas (ROA) terhadap PBV pada perusahaan food and beverage yang terdaftar di BEI, (2) adakah pengaruh leverage (DER) terhadap PBV pada perusahaan food and beverage yang terdaftar di BEI, (3) adakah pengaruh inflasi terhadap PBV pada perusahaan food and beverage yang terdaftar di BEI, dan (4) adakah pengaruh profitabilitas (ROA), tingkat leverage (DER), dan inflasi secara bersamaan terhadap PBV pada perusahaan food and beverage yang terdaftar di BEI.

Tujuan dari penelitian adalah untuk membuktikan dan menjelaskan bahwa profitabilitas (ROA) berpengaruh terhadap PBV pada perusahaan food and beverage di BEI, leverage (DER) berpengaruh terhadap PBV pada perusahaan food and beverage di BEI, inflasi berpengaruh terhadap PBV pada perusahaan food and beverage di BEI, dan profitabilitas NPM, leverage (DER), dan inflasi secara simultan berpengaruh terhadap PBV pada perusahaan food and beverage di BEI.

Pembatasan masalah dari penelitian ini hanya terfokus pada pengaruh : (1) Profitabilitas yang diukur dengan Return on Asset; (2) Leverage yang diukur dengan Debt to Equity Ratio; (3) Inflasi sebagai faktor eksternal. Sedangkan variabel dependennya adalah Price to Book Value yang menjadi isu permasalahan tersebut.

\section{TELAAH LITERATUR DAN PENGEMBANGAN HIPOTESIS}

\section{Grand Theory}

\section{a. Agency Theory (Teori Keagenan)}

Teori keagenan merupakan versi game theory yang memodelkan proses kontrak antara dua orang atau lebih dan masing-masing pihak yang terlibat dalam kontrak mencoba mendapatkan yang terbaik bagi dirinya (Estiyanti dan Yasa, 2011). Inti teori keagenan adalah konflik kepentingan antara agen dan prinsipal. Biaya keagenan yang timbul akibat adanya konflik kepentingan ini adalah biaya pengawasan (monitoring costs), biaya penjaminan (bonding costs), dan rugi residual (residual loss). Pihak principal termotivasi untuk pengembalian sebesar-besarnya dan secepatnya atas investasi yang telah dilakukannya melalui kinerja keuangan perusahaan yang pada umumnya diharapkan selalu meningkat.

\section{b. Signalling Theory (Teori Sinyal)}

Teori signal menunjukkan adanya hubungan asimetri antara manajemen dengan berbagai pihak yang berkepentingan terhadap informasi perusahaan (Raharja dan Sari, 2008). Asimetri informasi muncul karena adanya salah satu pihak yang mempunyai informasi lebih baik dibanding dengan pihak lainnya, misalnya seorang manajer yang mengetahui informasi mengenai prospek perusahaan yang lebih baik dibandingkan dengan para investornya. Berkaitan dengan asimetri informasi, sangat sulit bagi para investor dan kreditur untuk membedakan antara perusahaan yang berkualitas tinggi dan rendah. Teori signal mengemukakan bagaimana seharusnya perusahaan memberikan signal pada pengguna laporan keuangan.

\section{Middle Theory}

\section{a. Analisis Rasio Keuangan}

Laporan keuangan merupakan laporan posisi keuangan pada suatu titik, kegiatan operasi dalam suatu periode dan perubahan posisi keuangan serta catatan terkait laporan keuangan. Sugiono (2010) menyebutkan "perlunya menganalisa laporan keuangan adalah untuk dapat memperluas serta mempertajam informasi" ia juga menyatakan bahwa analisis laporan keuangan dipergunakan untuk menilai laporan keuangan perusahaan.

Dengan menggunakan teknik analisis rasio, analis dapat memberikan penilaian kinerja keuangan sebuah perusahaan. Helfert (2003) menjelaskan bahwa rasio keuangan dapat bermanfaat menunjukkan perubahan dalam kondisi keuangan atau kinerja perusahaan, dan dapat membantu menggambarkan ke- 
cenderungan serta pola perusahan tersebut, sehingga dapat menunjukkan peluang ataupun resiko perusahaan yang sedang ditelaah analis.

Analisis rasio keuangan menurut Mardiyanto (2009) dapat digolongkan menjadi 3 kelompok. Yang pertama dengan rata-rata industri dan pesaing yang unggul, ini merupakan kelompok cross-sectional (analisis silang), yaitu membandingkan rasio pada waktu (tahun) yang sama. Sedangkan yang kedua adalah analisis dengan data historis dan anggaran serta realisasinya termasuk analisis time-series (runtun waktu), yaitu membandingkan rasio dengan waktu yang berbeda. Yang terakhir adalah kelompok jenis analisis gabungan. Analisis gabungan adalah gabungan dari cross-sectional dan time-series. Sebagai contoh, jika suatu perusahaan mendapatkan retun on asset (ROA) tahun ini meningkat dibanding tahun lalu tetapi hasil tersebut masih di bawah rata-rata industri tahun ini maka perusahaan tersebut masih memiliki kinerja yang kurang memuaskan dan harus diperbaiki ditahun mendatang.

\section{b. Nilai Perusahaan (Price to Book Value)}

Rasio harga saham terhadap nilai buku perusahaan atau price book value (PBV), menunjukkan tingkat kemampuan perusahaan menciptakan nilai relatif terhadap jumlah modal yang diinvestasikan. PBV yang tinggi mencerminkan harga saham yang tinggi dibandingkan nilai buku per lembar saham. Semakin tinggi harga saham, semakin berhasil perusahaan menciptakan nilai bagi pemegang saham. Keberhasilan perusahaan menciptakan nilai tersebut tentunya memberikan harapan kepada pemegang saham berupa keuntungan yang lebih besar pula (Sartono, 2008).

Nilai perusahaan pada dasarnya dapat diukur melalui beberapa aspek, salah satunya adalah harga pasar saham perusahaan karena harga pasar saham perusahaan mencerminkan penilaian investor keseluruhan atas setiap ekuitas yang dimiliki. Fama (1978) dalam penelitiannya menggunakan pendekatan konsep nilai pasar untuk mengukur nilai perusahaan. Nilai pasar berbeda dengan nilai buku. Jika nilai buku merupakan harga yang dicatat pada nilai saham perusahaan, maka nilai pasar adalah harga saham yang terjadi di pasar bursa tertentu oleh permintaan dan penawaran saham tersebut oleh pelaku pasar. Nilai perusahaan merupakan nilai yang diberikan pasar bursa kepada manajemen perusahaan.

Pengukuran nilai perusahaan dalam penelitian ini akan menggunakan proksi yaitu Price to Book Value pada periode yang telah ditentukan. Menurut Prayitno dalam Wulandari (2009), Price to Book Value (PBV) menggambarkan seberapa besar pasar menghargai nilai buku saham suatu perusahaan. Makin tinggi rasio ini, berarti pasar percaya akan prospek perusahaan tersebut. Semakin tinggi rasio PBV, semakin tinggi kinerja perusahaan dinilai oleh pemodal dengan dana yang telah ditanamkan di perusahaan. Oleh karena itu dapat disimpulkan semakin tinggi PBV semakin tinggi tingkat kepercayaan pasar terhadap prospek perusahaan, maka akan menjadi daya tarik bagi investor untuk membeli saham tersebut, sehingga permintaan akan naik, kemudian mendorong harga saham naik (Wulandari, 2009).

Menurut Damodaran (2001) rasio PBV mempunyai beberapa keunggulan sebagai berikut:

1. Nilai buku mempunyai ukuran intutif yang relatif stabil yang dapat diperbandingkan dengan harga pasar. Investor yang kurang percaya dengan metode discounted cash flow dapat menggunakan price book value sebagai perbandingan.

2. Nilai buku memberikan standar akuntansi yang konsisten untuk semua perusahaan. PBV dapat diperbandingkan antara perusahaan-perusahaan yang sama sebagai petunjuk adanya under atau overvaluation.

3. Perusahaan-perusahaan dengan earning negatif, yang tidak bisa dinilai dengan menggunakan price earning ratio (PER) dapat dievaluasi menggunakan price book value ratio (PBV).

$$
\text { Price To Book Value }=\frac{\text { Harga pasar saham per lembar }}{\text { Nilai buku saham per lembar }}
$$

\section{Applicated Theory}

Faktor-faktor yang mempengaruhi nilai perusahaan pada penelitian ini adalah :

\section{a. Profitabilitas}

Profitabilitas perusahaan adalah kemampuan perusahaan untuk menghasilkan laba yang tinggi dan juga untuk mengetahui efektifitas perusahaan dalam mengelola sumber-sumber yang dimiliki. Profitabilitas perusahaan dihitung dan diproyeksikan dengan return on asset (ROA). Profitabilitas merupakan gambaran dari kinerja manajemen dalam mengelola perusahaan (Petronila dan Mukhlasin, 2003). Ukuran profitabilitas perusahaan dapat berbagai macam seperti : laba operasi, laba bersih, tingkat pengembalian invetasi/aktiva, dan tingkat pengembalian ekuitas pemilik. Ang (2010) mengungkapkan bahwa rasio 
profitabilitas atau rasio rentabilitas menunjukan keberhasilan perusahaan dalam menghasilkan keuntungan.

\section{b. Leverage}

Rasio leverage merupakan rasio yang menunjukkan tingkat proporsi penggunaan utang dalam membiayai investasi terhadap modal yang dimiliki. Rasio ini digunakan untuk mengukur sejauh mana suatu perusahaan menggunakan utang dalam membiayai investasinya. Perusahaan yang tidak mempunyai leverage berarti menggunakan modal sendiri 100\%. Pecking Order Theory menjelaskan sumber dana yang disukai perusahaan adalah internal financing (pendanaan hasil operasi). Jika dana internal masih belum mencukupi, maka dibutuhkan pendanaan dari hasil utang (obligasi) serta penerbitan saham baru. Perusahaan yang hanya menggunakan pendanaan hasil operasi kurang maksimal karena menambah persentase pajak. Akan tetapi jika perusahaan utang, maka akan mendapatkan manfaat untuk perkembangan usaha. Utang diperbolehkan sejauh masih memberikan manfaat, karena utang dalam jumlah yang besar dapat menyebabkan kebangkrutan bagi perusahaan (Husnan, 2003).

Salah satu alat yang dipakai untuk mengukur leverage adalah dengan menggunakan debt to equity ratio (DER). Menurut Brigham \& Houston (2011), sebuah perusahaan yang menggunakan pendanaan melalui utang, memiliki tiga implikasi penting : (1) Dengan memperoleh dana melalui utang, para pemegang saham dapat mempertahankan kendali mereka atas perusahaan tersebut dengan sekaligus membatasi investasi yang mereka berikan. (2) Kreditur akan melihat pada ekuitas atau dana yang diperoleh sendiri sebagai suatu batasan keamanan, sehingga semakin tinggi proporsi dari jumlah modal yang diberikan oleh pemegang saham, maka semakin kecil resiko yang harus dihadapi oleh kreditur. (3) Jika perusahaan mendapatkan hasil dari investasi yang didanai dengan dana hasil pinjaman lebih besar daripada bunga yang dibayarkan, maka pengembalian dari modal pemilik akan diperbesar atau diungkit (leverage).

Dalam kondisi perekonomian normal, perusahaan-perusahaan yang memiliki rasio utang relatif tinggi akan memiliki ekspektasi pengembalian yang juga lebih tinggi, namun di masa resesi, di mana penjualan merosot tajam, laba yang dihasilkan tidak cukup untuk menutup bunga pinjaman, kas akan menyusut dan kemungkinan perusahaan perlu mendapatkan tambahan dana. Karena beroperasi dalam keadaan rugi, perusahaan akan kesulitan menjual sahamnya, di sisi lain para kreditur akan meningkatkan tingkat suku bunga karena meningkatnya resiko kerugian.

\section{c. Inflasi}

Menurut Wibowo (2012), inflasi adalah suatu proses meningkatnya harga-harga secara umum dan terus menerus (kontinu) berkaitan dengan mekanisme pasar yang dapat disebabkan oleh berbagai faktor, antara lain, konsumsi masyarakat yang meningkat, berlebihnya likuiditas di pasar yang memicu konsumsi atau bahkan spekulasi, sampai termasuk juga akibat adanya ketidaklancaran distribusi barang. Dapat diartikan sebagai proses menurunnya nilai mata uang secara kontinu. Inflasi adalah proses dari suatu peristiwa, bukan tinggi-rendahnya tingkat harga. Inflasi adalah indikator untuk melihat tingkat perubahan, dan dianggap terjadi jika proses kenaikan harga berlangsung secara terus-menerus dan saling mempengaruhi. Istilah inflasi juga digunakan untuk mengartikan peningkatan persediaan uang yang kadangkala dilihat sebagai penyebab meningkatnya harga. Ada banyak cara untuk mengukur tingkat inflasi. Inflasi terbagi menjadi 4 tingkatan, yaitu :

1. Inflasi Ringan, apabila kenaikan harga berada di bawah $10 \%$ setahun.

2. Inflasi Sedang, apabila kenaikan harga berada di antara 10\%-30\% setahun

3. Inflasi Berat, apabila kenaikan harga berada di antara $30 \%-100 \%$ setahun

4. Hiperinflasi, apabila kenaikan harga di atas $100 \%$ setahun

Menurut Kasmir (2010) menyatakan inflasi adalah proses kenaikan harga barang secara umum dan terus menerus dalam waktu periode yang diukur dengan menggunakan indeks harga. Tingkat pengembalian investasi saham berkorelasi positif dengan nilai rill dan tingkat pengembalian investasi berkorelasi negatif dengan tingkat suku bunga dan inflasi. Indeks harga dalam mengukur inflasi antara lain:

1. Indeks harga konsumen, digunakan untuk mengukur biaya - biaya barang dan jasa yang dibeli untuk menunjang kebutuhan hidup sehari - hari dengan perubahan indeks harga dari tahun ketahun.

2. Indeks perdagangan besar, merupakan usaha yang menitik beratkan pada sejumlah barang pada tingkat perdagangan besar. Ini berarti harga bahan mentah atau bahan jadi masuk dalam perhitungan indeks harga. 
3. Gross Net Product (GNP) deflator, merupakan suatu jenis indeks harga yang sangat berbeda dengan dua jenis indeks diatas yang mencakup dalam jumlah barang dan jasa yang jumlah perhitungannya menjadi lebih banyak dibanding dengan dua indeks diatas.

\section{Penelitian Terdahulu}

Berbagai penelitian telah dilakukan untuk mengetahui faktor-faktor yang mempengaruhi price book value (PBV). Wira Hadi Anugraha (2013) meneliti tentang pengaruh variabel fundamental terhadap nilai perusahaan yang diproksikan dengan PBV. Obyek dari penelitian ini yaitu perusahaan sub sektor otomotif dan komponen yang terdaftar di Bursa Efek Indonesia tahun 2009-2012. Teknik analisis dengan analisa regrasi berganda. Hasil penelitian menyimpulkan bahwa keputusan investasi yang diproksikan dengan PER tidak berpengaruh terhadap PBV, keputusan pendanaan yang diproksikan dengan DER berpengaruh negatif namun tidak signifikan terhadap PBV, Size yang diproksikan dengan Total Asset dan Profitabilitas yang diproksikan dengan ROE berpengaruh positif dan signifikan terhadap PBV. Secara simultan PER, DER, Total Asset dan ROE berpengaruh signifikan terhadap PBV.

Wardjono (2010) menguji faktor-faktor yang mempengaruhi PBV dan implikasinya terhadap return saham di perusahaan manufaktur yang terdaftar di BEI. Teknik analisa regresi linier berganda. Hasil penelitian menyatakan bahwa ROE dan Growth berpengaruh positif dan signifikan terhadap PBV, sedangkan DPR dan DFL tidak berpengaruh secara signifikan terhadap PBV. PBV berpengaruh secara positif dan signifikan terhadap Return Saham.

Hidayati (2010) meneliti pengaruh DPR, ROE, dan Size terhadap PBV Perusahaan Manufaktur yang listing di BEI Periode 2005-2007. Teknik analisa regresi linier berganda. Hasil penelitian menyimpulkan DER dan DPR berpengaruh negatif dan tidak signifikan terhadap PBV. ROE dan Size berpengaruh positif dan signifikan terhadap PBV.

Rosma Pakpahan (2010), meneliti perusahaan manufaktur yang terdaftar di bursa efek Indonesia selama tahun 2003-2007. Penelitian ini menggunakan analisa regresi berganda. Hasil penelitiannya disimpulkan bahwa Secara simultan Size, Growth, Leverage, Return On Equity, Devidend Payout Ratio berpengaruh signifikan terhadap nilai perusahaan yang diproksikan dengan Price to Book Value. Secara parsial, Size dan Return On Equity berpengaruh positif dan signifikan, sedangkan Growth, Leverage, dan Devidend Payout Ratio tidak berpengaruh signifikan terhadap nilai perusahaan.

Ni Gusti Putu Wirawati (2008), meneliti perusahaan manufaktur yang terdaftar di bursa efek Jakarta selama tahun 1998-2000. Penelitian ini menggunakan analisis regresi berganda. Dalam penelitiannya menemukan dari keempat faktor fundamental yang dianalisis menunjukkan bahwa variable Return on Equity (ROE) dan Devidend Payout Ratio (DPR) mempunyai hubungan yang positif dan signifikan terhadap price book value.

Ekayana (2007) menguji tentang pengaruh insideran ownership, kebijakan hutang, profitabilitas dan ukuran perusahaan terhadap nilai perusahaan yang diproxykan oleh price book value. Obyek dari penelitian ini yaitu yang perusahaan manufaktur yang listing di BEI tahun 2001-2005. Teknik analisis menggunakan regresi dengan pendekatan fixed effect model (FEM). Hasil penelitian ini mengemukakan kebijakan hutang yang diwakilkan oleh debt to equity ratio dan ukuran perusahaan yang diwakilkan oleh total asset berpengaruh positif dan signifikan terhadap price book value.

\section{Hubungan antara Profitabilitas dan Nilai Perusahaan}

Profitabilitas menunjukan kemampuan perusahaan memperoleh laba baik dalam hubunganya dengan penjualan, total aktiva maupun laba bagi modal sendiri. Profitabilitas ini memberikan gambaran seberapa efektif perusahaan beroperasi sehingga memberikan keuntungan bagi perusahaan. Perusahaan yang memiliki profitabilitas tinggi akan memberikan sinyal akan keberhasilan perusahaan dalam memberikan pengembalian kepada pemilik saham. ROA yang tinggi akan menyebabkan investor memburu suatu saham perusahaan akibatnya nilai perusahaan tersebut akan meningkat pula.

\section{Hubungan antara Leverage dan Nilai Perusahaan}

Rasio leverage yang merupakan pengukur tingkat proporsi penggunaan utang untuk kegiatan investasi. Jika perusahaan memiliki kesempatan utang maka dapat menambah manfaat perusahaan untuk melakukan expansi usaha. Proporsi utang yang baik adalah adanya keseimbangan antara hasil utang dengan kemampuan pelunasan kewajiban perusahaan. Semakin besar hutang perusahaan maka semakin besar pula risiko yang dihadapi investor sehingga investor akan meminta tingkat keuntungan yang semakin tinggi dan harga saham cenderung menurun karena financial distress ini. 


\section{Hubungan antara Inflasi dan Nilai Perusahaan}

Moch. Ronni dan Abdul Muid (2012) inflasi adalah indikator ekonomi yang menggambarkan turunnya nilai rupiah, dan kondisi ini ditandai dengan meningkatnya harga barang-barang kebutuhan di pasar. Meningkatnya inflasi dapat menurunkan daya beli masyarakat, karena harga-harga barang kebutuhan meningkat sedangkan, pendapatan masyarakat tetap. Sehingga inflasi sering menjadi suatu masalah terutama jika pemerintah tidak berhasil atau tidak mampu mengendalikan laju pertumbuhan.

Berdasarkan konsep dan teori sebagaimana diuraikan sebelumnya, maka dibangun kerangka pemikiran yang dapat digunakan sebagai paradigma penelitian yang bertujuan melihat sejauh mana pengaruh profitabilitas, leverage, dan inflasi terhadap nilai perusahaan.

Gambar 1

Kerangka Pemikiran

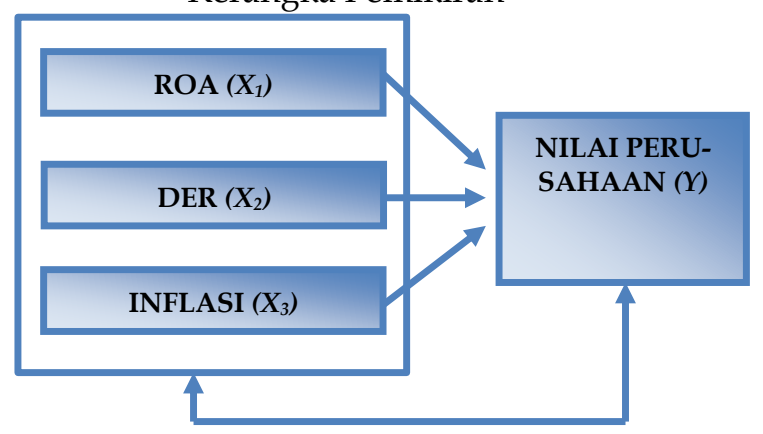

Berdasarkan kerangka pemikiran dan kajian teori sebelumnya dengan latar belakang permasalahan yang sudah di paparkan, maka hipotesis alternatif dalam penelitian ini dapat dirumuskan sebagai berikut : $\mathrm{H}_{1}$ : PROFITABILITAS (RETURN ON ASSET) BERPENGARUH TERHADAP NILAI PERUSAHAAN $\mathrm{H}_{2}$ : LEVERAGE (DEBT TO EQUITY RATIO) BERPENGARUH TERHADAP NILAI PERUSAHAAN $\mathrm{H}_{3}$ : INFLASI BERPENGARUH TERHADAP NILAI PERUSAHAAN $\mathrm{H}_{4}$ : PROFITABILITAS, LEVERAGE, DAN INFLASI SECARA SIMULTAN BERPENGARUH TERHADAP NILAI PERUSAHAAN

\section{METODE PENELITIAN}

Penelitian ini termasuk ke dalam jenis penelitian kuantitatif yang mana data kuantitatif tersebut adalah data sekunder. Data sekunder yang digunakan berupa data laporan keuangan auditan perusahaan yang terdaftar di Bursa Efek Indonesia dalam Indonesian Capital Market Directory (ICMD), dan situs BEI (www.idx.co.id) periode laporan keuangan tahun 2012 - 2017. Adapun subjek yang diteliti yaitu perusahaan-perusahaan yang termasuk dalam sektor food and beverage. Populasi yang digunakan dalam penelitian ini adalah seluruh perusahaan food and beverage yang terdaftar (listing) di Bursa Efek Indonesia (BEI) pada tahun 2012 - 2017. Pengambilan sampel dalam penelitian ini adalah dengan teknik purposive sampling dengan tujuan untuk mendapatkan sampel yang representatif sesuai dengan kriteria sampel, beberapa diantaranya adalah perusahaan menerbitkan laporan keuangan (audited) selama periode 2012 sampai dengan 2017. Pengambilan sampel berdasarkan kriteria-kriteria :

Tabel 1.

Kriteria Sampel Penelitian

\begin{tabular}{|c|l|c|}
\hline No. & \multicolumn{1}{|c|}{ Keterangan } & $\begin{array}{c}\text { Jumlah } \\
\text { Perusahaan }\end{array}$ \\
\hline 1. & $\begin{array}{l}\text { Perusahaan yang terdaftar } \\
\text { pada BEI sektor food and } \\
\text { beverage periode 2012-2017 }\end{array}$ & 16 \\
\hline 2. & $\begin{array}{l}\text { Perusahaan tidak secara kon- } \\
\text { sisten terdaftar di BEI sektor } \\
\text { food and beverage periode } \\
\text { 2012-2017 }\end{array}$ & (4) \\
\hline 4. & $\begin{array}{l}\text { Perusahaan yang tidak men- } \\
\text { gungkapkan semua variabel }\end{array}$ & (2) \\
\hline
\end{tabular}




\begin{tabular}{|c|l|c|}
\hline & $\begin{array}{l}\text { penelitian (data tidak leng- } \\
\text { kap) }\end{array}$ & 10 \\
\hline 5. & Total sampel perusahaan & 60 \\
\hline 6. & $\begin{array}{l}\text { Jumlah sampel observasi } \\
\text { selama periode penelitian } \\
\text { total sampel perusahaan } \\
\text { selama 6 tahun periode pene- } \\
\text { litian) }\end{array}$ \\
\hline
\end{tabular}

Sumber data: Data BEI, diolah

Tabel di bawah ini menunjukkan bahwa dari emiten yang terdaftar pada Bursa Efek Indonesia (BEI) sektor food and beverage periode 2012 - 2017, ada 10 emiten yang memenuhi karakteristik sampel yang telah ditentukan. Daftar perusahaan-perusahaan tersebut dapat dilihat dalam tabel berikut :

Tabel 2.

Sampel Penelitian

\begin{tabular}{|c|l|c|}
\hline No. & Kode & Nama Emiten \\
\hline 1. & ADES & Akasha Wira International Tbk \\
\hline 2. & AISA & Tiga Pilar Sejahtera Food Tbk \\
\hline 3. & CEKA & Cahaya Kalbar Tbk \\
\hline 4. & DLTA & Delta Djakarta Tbk \\
\hline 5. & MLBI & Multi Bintang Indonesia Tbk \\
\hline 7. & INDF & Indofood Sukses Makmur Tbk \\
\hline 8. & SKLT & Sekar Laut Tbk \\
\hline 9. & STTP & Siantar Top Tbk \\
\hline 10. & ULTJ & Ultra Jaya Milk Ind.Tbk \\
\hline
\end{tabular}

Sumber: Data diolah

Metode pengumpulan data yang dilakukan adalah metode dokumentasi, yaitu data yang diperoleh dari berbagai dokumen atau literatur yang berkaitan dengan permasalahan yang sedang diteliti. Setelah dokumentasi, dikumpulkan, diseleksi, dan kemudian diolah. Variabel yang digunakan dalam penelitian ini adalah variabel dependen yang berupa Price to Book Value. Sedangkan variabel independennya adalah profitabilitas, leverage dan inflasi.

Tabel 3.

Operasionalisasi Variabel

\begin{tabular}{|l|l|l|l|c|}
\hline No & $\begin{array}{l}\text { Var Pene- } \\
\text { litian }\end{array}$ & Dimensi & \multicolumn{1}{|c|}{ Indikator } & $\begin{array}{c}\text { Ska- } \\
\text { la }\end{array}$ \\
\hline 1 & $\begin{array}{l}\text { Nilai } \\
\text { Perusa- } \\
\text { haan }\end{array}$ & $\begin{array}{l}\text { Price To } \\
\text { Book } \\
\text { Value }\end{array}$ & $\begin{array}{l}\text { PBV } \\
\text { Closing Price }\end{array}$ & Rasio \\
\hline 2 & $\begin{array}{l}\text { Profitabi- } \\
\text { litas }\end{array}$ & $\begin{array}{l}\text { Return } \\
\text { On As- } \\
\text { sets }\end{array}$ & $\begin{array}{l}\text { NPM } \\
=\frac{\text { Net Income }}{\text { Sales }}\end{array}$ & Rasio \\
\hline 3 & Leverage & $\begin{array}{l}\text { Debt To } \\
\text { Equity } \\
\text { Ratio }\end{array}$ & $\begin{array}{l}\text { DER Total Liability } \\
=\frac{\text { Total Equity }}{\text { Thasio }}\end{array}$ & Rasio \\
\hline 4 & Inflasi & $\begin{array}{l}\text { Persen- } \\
\text { tase In- } \\
\text { flasi }\end{array}$ & $\begin{array}{l}\text { Rata-rata Inflasi } \\
\text { per satu tahun }\end{array}$ & Rasio \\
\hline
\end{tabular}

Sumber : Data diolah

Metode yang dipakai dalam menganalisis variabel-variabel dalam penelitian ini adalah menggunakan regresi linier berganda. Analisis regresi linear berganda digunakan untuk mengetahui atau memperoleh gambaran mengenai pengaruh variabel independen pada variabel dependen dan bertujuan untuk mengestimasi dan atau memprediksi rata-rata populasi atau nilai rata-rata variabel dependen berdasarkan nilai variabel independen yang diketahui (Ghozali, 2011). Analisis regresi linier berganda merupakan analisis yang digunakan untuk mencari adanya hubungan antara dua variabel independen atau lebih terhadap 
satu variabel dependen. Model yang digunakan dalam penelitian ini adalah:

$Y=a+b_{1} X_{1}+b_{2} X_{2}+b_{3} X_{3}+e$

Keterangan:

Y : Price to Book Value

$\mathrm{X}_{1} \quad$ :Return on Asset

$\mathrm{X}_{2} \quad$ : Debt equity ratio

$\mathrm{X}_{3} \quad$ : Inflasi

a : Nilai intersep (konstan)

b : Koefisien arah regresi

\section{HASIL PENELITIAN DAN PEMBAHASAN}

Statistik deskriptif digunakan untuk mengetahui gambaran dari masing-masing variabel yang digunakan dalam penelitian. Dari analisis tersebut, dapat diketahui nilai minimum, maksimum, rata-rata (mean), dan standar deviasi dari masing-masing variabel. Berikut ini merupakan statistik deskriptif dari masing-masing variabel independen dalam penelitian ini.

Tabel 4

Statistik Deskriptif

\begin{tabular}{|l|r|r|r|}
\hline & \multicolumn{1}{|c|}{ Mean } & \multicolumn{1}{c|}{$\begin{array}{c}\text { Standar } \\
\text { Deviation }\end{array}$} & N \\
\hline PBV & 8.6578 & 6.92573 & 54 \\
\hline ROA & 2.2194 & 1.26093 & 54 \\
\hline DER & 1.003 & 0.55683 & 54 \\
\hline Inflasi & 5.16667 & 2.31198 & 54 \\
\hline
\end{tabular}

Sumber : Data Diolah

Hasil pengolahan data berdasarkan analisis statistik deskriptif pada tabel di atas menunjukkan bahwa:

a. Price to Book Value (PBV)

PBV memiliki nilai rata-rata (mean) 8,6578 dan deviasi standarnya menunjukkan nilai 6,92573, nilainya lebih kecil dari rata-rata sehingga penyebaran datanya homogen.

b. Return on Asset (ROA)

Pada variabel ROA memiliki nilai rata-rata (mean) menunjukkan nilai 2,2194 dan deviasi standarnya menunjukkan nilai 1,26093 nilainya lebih kecil dari rata-rata sehingga penyebaran datanya homogen.

c. Debt to equity ratio (DER)

Pada variabel DER memiliki nilai rata-rata (mean) 1,0030 yang berarti rata-rata perusahaan memiliki hutang sebear 1,0030 kali dan deviasi standarnya menunjukkan nilai 0,55683.

d. Inflasi

Pada variabel inflasi memiliki nilai rata-rata (mean) sebesar 5,1667 sedangkan deviasi standar menunjukkan nilai 2,31198 nilainya lebih kecil dari rata-ratanya yang menunjukkan bahwa tingkat penyebaran datanya homogen.

\section{Uji Normalitas}

Uji normalitas dalam penelitian ini dilakukan dengan menggunakan analisis Grafik Normal P-P Plot dan uji one sample Kolmogorov-Smirnov test dengan melihat angka signifikansi dari variabel unstandardized residual yang diproses menggunakan program aplikasi SPSS. Uji normalitas dilakukan setelah melalui tahap uji outlier, yaitu aktivitas menghilangkan data yang memiliki karakteristik unik yang terlihat sangat berbeda jauh dari data observasi lainnya dan muncul dalam bentuk nilai ekstrim. Setelah mengeluarkan data outlier, tersisa 54 sampel observasi. 
Tabel 5

Uji Normalitas

\begin{tabular}{|ll|r|}
\hline & & $\begin{array}{r}\text { Unstandardized } \\
\text { Residual }\end{array}$ \\
\hline $\mathrm{N}$ & Mean & 54 \\
Normal Parameters & Std Deviation & 0.0000000 \\
Most Extreme Differences & Absolute & 1.88678571 \\
& Positive & 1.79 \\
& Negative & -0.061 \\
Kolmogorov-Smirnov Z & & 1.204 \\
Asymp. Sig (2-tailed) & & 0.110 \\
\hline
\end{tabular}

Hasil uji normalitas setelah melalui uji outlier menunjukkan bahwa variabel terikat PBV dan variabel bebas (ROA, DER, dan Inflasi) memiliki residual yang terdistribusi normal. Hal ini ditunjukkan dengan nilai signifikasi asymp. sig. (2-tailed) sebesar 0.110, lebih besar dari 0,05. Deteksi normalitas pada suatu variabel juga dapat dilakukan dengan cara melihat plot probabilitas normal. Uji normalitas menggunakan plot probabilitas telah terpenuhi karena titik-titik (data-data observasi) terkumpul di sekitar garis lurus.

\section{Uji Multikolinearitas}

Uji multikolinearitas dapat dilihat dari nilai tolerance dan variance inflation faktor (VIF). Berikut adalah dilihat hasil uji multikolinearitas :

Tabel 6

Uji Multikolinearitas

\begin{tabular}{|l|r|r|}
\hline \multirow{2}{*}{ Model } & \multicolumn{2}{|c|}{ Collinearity Statistics } \\
\cline { 2 - 3 } & Tolerance & VIF \\
\hline (Constant) & & \\
ROA & 0.750 & 1.334 \\
DER & 0.745 & 1.343 \\
Inflasi & 0.981 & 1.019 \\
\hline
\end{tabular}

Sumber : Data Diolah

Berdasarkan tabel di atas, dapat diketahui bahwa semua variabel independen, yaitu ROA, DER, dan Inflasi memiliki nilai tolerance lebih besar dari 0,10 dan nilai VIF lebih kecil dari 10. Berdasarkan hasil tersebut, tidak terdapat multikolineritas, sehingga data memenuhi kriteria untuk digunakan dalam model regresi.

\section{Uji Autokorelasi}

Pengujian autokorelasi dilakukan dengan menggunakan uji Durbin-Watson. Hasil uji autokorelasi menunjukan bahwa nilai Durbin-Watson sebesar 1,827. Dengan significance level 0,05, jumlah sampel 54, dan variabel bebas (k) 3, maka pada tabel Durbin-Watson diperoleh nilai dl $(1,4464)$ dan nilai du $(1,6800)$. Nilai Durbin-Watson pada model penelitian berada diantara batas atas (du) dan (4-du), $(1,6800<1,827<$ $2,320)$ maka tidak ada autokorelasi.

\section{Uji Heteroskedastisitas}

Dari hasil uji heteroskedastisitas, diketahui bahwa titik-titik menyebar secara acak serta tersebar baik di atas maupun di bawah angka 0 pada sumbu Y, sehingga dapat disimpulkan tidak terjadi gejala heteroskedastisitas dalam model regresi.

\section{Uji t}

Uji t pada dasarnya menunjukkan seberapa besar pengaruh satu variabel independen secara parsial terhadap variabel dependen, dalam model regresi pada penelitian ini untuk menguji pengaruh ROA, DER, dan Inflasi secara parsial terhadap PBV. Untuk melakukan uji hipotesis biasanya digunakan uji t-test atau uji signifikan, level signifikansi dalam penelitian ini sebesar $5 \%(0,05)$. Hasil uji t adalah sebagai berikut : 


\begin{tabular}{|c|c|c|c|c|c|}
\hline \multicolumn{6}{|c|}{ Tabel 7} \\
\hline \multirow[t]{2}{*}{ Model } & \multicolumn{2}{|c|}{$\begin{array}{c}\text { Unstandardized } \\
\text { Coefficients }\end{array}$} & \multirow{2}{*}{\begin{tabular}{|c|}
$\begin{array}{c}\text { Standardi } \\
\text { zed Coef }\end{array}$ \\
Beta \\
\end{tabular}} & \multirow[t]{2}{*}{$\mathrm{t}$} & \multirow[t]{2}{*}{ Sig. } \\
\hline & B & Std. Error & & & \\
\hline (Constant) & -0.017 & 2.833 & & -0.006 & 0.995 \\
\hline ROA & 3.928 & 0.636 & 0.715 & 6.176 & 0.000 \\
\hline DER & 0.242 & 0.242 & 0.19 & 0.167 & 0.868 \\
\hline Inflasi & -0.055 & -0.303 & -0.018 & -0.183 & 0.856 \\
\hline
\end{tabular}

Nilai signifikansi ROA sebesar $(0,000)$ lebih kecil dari 0,05 maka Ha diterima, yang berarti ROA berpengaruh secara signifikan terhadap Price to Book Value. Nilai signifikansi DER $(0,868)$ lebih besar dari 0,05 maka Ha ditolak, yang berarti DER tidak berpengaruh secara signifikan terhadap Price to Book Value. Nilai signifikansi Inflasi (0,858 lebih besar dari 0,05 maka Ha ditolak, yang berarti Inflasi tidak berpengaruh secara signifikan terhadap Price to Book Value. Berdasarkan tabel diatas, persamaan model regresi linear berganda dalam penelitian ini dapat dinyatakan sebagai berikut:

PBV $=-0,017+3,928$ ROA + 2,42 DER -0,055 Inflasi $+\varepsilon$

Penjelasan mengenai pengaruh variabel-variabel independen terhadap variabel dependen secara parsial diuraikan sebagai berikut:

1. Konstanta

Nilai konstanta sebesar -0,017 berarti jika variabel ROA, DER dan Inflasi adalah nol maka nilai kinerja pengawasan adalah sebesar konstanta yaitu $-0,017$.

2. Return on Asset (ROA)

Nilai koefisien regresi ROA adalah 3,928 berarti apabila nilai koefisien regresi variabel independen lainnya tetap (tidak berubah), maka perubahan 1 (satu) satuan ROA akan menaikkan PBV sebesar 3,928 satuan.

3. Debt to Equity Ratio (DER)

Nilai koefisien regresi DER adalah sebesar 0,242. Artinya apabila nilai koefisien regresi variabel independen lainnya tetap (tidak berubah), maka perubahan 1 (satu) satuan DER menaikkan PBV sebesar 0,242 satuan.

4. Inflasi

Nilai koefisien regresi dari Inflasi sebesar -0,055. Artinya apabila nilai koefisien regresi variabel independen lainnya tetap (tidak berubah), maka perubahan 1 (satu) satuan inflasi menurunkan PBV sebesar 0,055 satuan.

\section{Uji F}

Pengujian dalam penelitian ini dilakukan dengan tingkat keyakinan 95\% ( $\alpha=5 \%$ ). Hasil uji F (Anova) menggunakan program aplikasi SPSS dengan hasil :

\begin{tabular}{|c|c|c|c|c|c|}
\hline \multicolumn{6}{|c|}{$\begin{array}{c}\text { Tabel } 8 \\
\text { Uji F }\end{array}$} \\
\hline Model & $\begin{array}{l}\text { Sum of } \\
\text { Squares }\end{array}$ & df & $\begin{array}{c}\text { Mean } \\
\text { Square }\end{array}$ & $\mathrm{F}$ & Sig. \\
\hline Regression & 1264.277 & 3 & 421.426 & & \\
\hline Residual & 1277.91 & 50 & 25.558 & 16.489 & 0.000 \\
\hline Total & 2542.187 & 53 & & & \\
\hline
\end{tabular}

Berdasarkan tabel diatas, p-value $(0,000)$ lebih kecil dari 0,05 . Hal ini mengindikasikan bahwa model regresi layak dan dapat digunakan untuk memprediksi atau variabel independen (ROA, DER, Inflasi) secara bersama-sama mempengaruhi variabel dependen (PBV).

\section{Koefisien Determinasi}

Setelah dilakukan pengujian terhadap model regresi linear berganda, diperoleh nilai koefisien determinasi sebagai berikut: 
Tabel 9

\begin{tabular}{|l|r|r|r|r|r|}
\hline Model & $\mathrm{R}$ & $\begin{array}{c}\mathrm{R} \\
\text { Square }\end{array}$ & $\begin{array}{c}\text { Adjusted } \\
\text { R Square }\end{array}$ & $\begin{array}{c}\text { Std Error of } \\
\text { The } \\
\text { Estimate }\end{array}$ & $\begin{array}{c}\text { Durbin } \\
\text { Watson }\end{array}$ \\
\hline 1 & 0.705 & 0.497 & 0.467 & 5.05551 & 1.872 \\
\hline
\end{tabular}

Sumber: Data Diolah

Nilai Koefisien determinasi (Adjusted R-Square) model regresi dalam penelitian ini adalah 0,467. Artinya, besarnya variasi variabel dependen PBV yang dapat dijelaskan oleh variasi variabel independen (ROA, DER, dan Inflasi) adalah sebesar 46,7\%, sedangkan sisanya sebesar 53,3\% dijelaskan oleh faktorfaktor lain yang dianggap tetap yang tidak dimasukkan ke dalam model regresi.

\section{Pengaruh Return on Asset (ROA) terhadap Price to Book Value (PBV)}

Hasil penelitian menunjukkan bahwa Return on Asset (ROA) berpengaruh terhadap Price to Book Value (PBV). Hasil analisis regresi menunjukkan bahwa ROA memiliki hubungan yang positif terhadap PBV, semakin besar ROA maka semakin besar PBV. Dengan demikian menerima H1 yang menyatakan bahwa Return on Asset berpengaruh signifikan terhadap PBV. Semakin tinggi Return on Asset semakin tinggi efisiensi perusahaan dalam kegiatan operasional perusahaan. Dengan efisiensi yang tinggi, kinerja perusahaan menjadi baik. Hal ini akan meningkatkan minat pemegang saham untuk berinvestasi. Jika pemegang saham yang ingin berinvestasi di sebuah perusahaan banyak, maka akan dapat berdampak pada naiknya harga saham. Dengan harga saham yang tinggi maka akan meningkatkan Price to Book Value (PBV) perusahaan.

\section{Pengaruh Debt to Equity Ratio (DER) terhadap Price to Book Value (PBV)}

Hasil penelitian menunjukkan bahwa Debt to Equity Ratio (DER) secara parsial tidak berpengaruh secara signifikan terhadap Price to Book Value (PBV). Analisis regresi menunjukkan bahwa DER tidak memiliki hubungan yang terhadap PBV, yang berarti jika DER meningkat maka PBV akan meningkat juga. Arah koefisien regresi variabel DER bertanda positif yang berarti bahwa peningkatan DER justru akan meningkatkan PBV. Mengindikasikan bahwa kebijakan hutang bukan dinilai sebagai sesuatu yang terlalu mengkhawatirkan perusahaan. Dalam hal ini kebijakan menambah hutang dipandang sebagai sebuah sinyal pertumbuhan perusahaan. Hasil penelitian ini didukung oleh penelitian Anugraha (2013) yang menyatakan bahwa DER tidak berpengaruh terhadap PBV, dan tidak sejalan dengan penelitian Putra, dkk (2007) yang menyatakan bahwa DER mempengaruhi PBV.

\section{Pengaruh Inflasi terhadap Price to Book Value (PBV)}

Hasil penelitian menunjukkan bahwa Inflasi secara signifikan tidak berpengaruh terhadap Price to Book Value $(P B V)$. Hasil analisis regresi menunjukkan bahwa Inflasi memiliki hubungan yang negatif terhadap PBV, semakin besar Inflasi maka semakin kecil PBV. Dengan demikian menolak $\mathrm{H}_{3}$ yang menyatakan bahwa Inflasi berpengaruh signifikan terhadap PBV.

\section{Pengaruh Return on Asset (ROA), Debt to Equity Ratio (DER), dan Inflasi secara simultan terhadap Market Value Added (MVA)}

Hasil penelitian menunjukkan bahwa Return on Asset (ROA), Debt to Equity Ratio (DER), dan Inflasi berpengaruh secara simultan terhadap Price to Book Value (PBV). Dengan demikian menerima $\mathrm{H}_{4}$ yang menyatakan bahwa Return on Asset (ROA), Debt to Equity Ratio (DER), dan Inflasi berpengaruh secara simultan terhadap Price to Book Value (PBV).

\section{SIMPULAN, KETERBATASAN DAN SARAN}

Berdasarkan hasil pengujian Return on Asset (ROA), Debt Equity Ratio (DER), dan Inflasi dalam memprediksi Price to Book Value (PBV) yang terdaftar pada Bursa Efek Indonesia (BEI) di sektor food and beverage selama periode 2012-2017 dengan menggunakan regresi linear berganda, maka dapat disimpulkan sebagai berikut:

1. Hasil pengujian dengan menggunakan regresi linear berganda membuktikan bahwa variabel Return on Asset (ROA) berpengaruh terhadap Price to Book Value (PBV). Dengan demikian menerima hipotesis 
pertama $\left(\mathrm{H}_{1}\right)$ yang menyatakan Return on Asset (ROA) berpengaruh signifikan terhadap Price to Book Value (PBV).

2. Hasil pengujian dengan menggunakan regresi linear berganda membuktikan bahwa variabel Debt Equity Ratio (DER) tidak berpengaruh terhadap Price to Book Value (PBV). Dengan demikian menolak hipotesis kedua $\left(\mathrm{H}_{2}\right)$ yang menyatakan Debt Equity Ratio (DER) berpengaruh terhadap Price to Book Value (PBV).

3. Hasil pengujian dengan menggunakan regresi linear berganda membuktikan bahwa variabel Inflasi tidak berpengaruh terhadap Price to Book Value (PBV). Dengan demikian menolak hipotesis ketiga $\left(\mathrm{H}_{3}\right)$ yang menyatakan terdapat pengaruh signifikan antara Inflasi dan Price to Book Value (PBV).

4. Hasil pengujian dengan menggunakan regresi linear berganda membuktikan bahwa variabel Return on Asset (ROA), Debt Equity Ratio (DER), dan Inflasi secara simultan berpengaruh terhadap Price to Book Value (PBV). Dengan demikian menerima hipotesis kelima $\left(\mathrm{H}_{5}\right)$ yang menyatakan terdapat pengaruh Return on Asset (ROA), Debt Equity Ratio (DER), dan Inflasi secara simultan terhadap Price to Book Value (PBV).

Saran yang dapat digunakan bagi pihak yang ingin melanjutkan penelitian ini adalah:

1. Penelitian selanjutnya dapat menambahkan faktor akuntansi lainnya yang tidak dimasukkan dalam model penelitian ini dengan pergantian proksi sebagai pengukuran variabel seperti Economic Value Added, ukuran (firm size), Net Profit Margin, Return on Equity, karateristik Industri, serta faktor nonakuntansi lainnya seperti tingkat suku bunga, kurs, dan inflasi.

2. Jumlah sampel dapat diambil dengan periode pengamatan yang lebih lama dan menggunakan datadata yang literatur Pusat Referensi Pasar Modal Bursa Efek Indonesia, Indonesian Capital Market Library (ICaMEL), Indonesian Capital Market Directory (ICMD), dan situs BEI (www.idx.co.id). Sehingga diharapkan hasil yang diperoleh akan lebih dapat di generalisasikan.

\section{DAFTAR PUSTAKA}

Abdul Muid, Moch. Ronni Noerirawan. 2012. Pengaruh Faktor Internal dan Eksternal Perusahaan Terhadap Nilai Perusahaan (Studi Empiris Pada Perusahaan Manufaktur Yang Terdaftar Di Bursa Efe k Indonesia Periode 2007-2010). Jurnal Akuntansi Volume 1 No.2 Hal. 4.

Ang, Robert, 2010. Buku Pintar Pasar Modal Indonesia $7^{\text {th }}$ Edition, Mediasoft Indonesia, Jakarta.

Anugraha, Wira Hadi, 2013. Pengaruh Variabel Fundamental Terhadap Nilai Perusahaan (Studi Empiris Pada Perusahaan Sub Sektor Otomotif dan Komponen yang Terdaftar di Bursa Efek Indonesia periode 2009-2012), eJournal Unsri.

Brigham, Eugene F and Houston, Joel F, 2011. Essential of Financial Management (terjemahan), Salemba Empat: Jakarta.

Damodaran, A, 2001. Corporate Finance : Theory and Practise, Second Edition, John Wiley \& Son, New York

Ekayana, 2007. Analisis Pengaruh Insider Ownership, Kebijakan Hutang, Profitabilitas dan Ukuran Perusahaan Terhadap Nilai Perusahaan (Studi Empiris Terhadap Perusahaan Manufaktur yang Terdaftar di Bursa Efek Jakarta tahun 2001-2005), Jurnal ASET Vol. 9 Nomer 2 Agustus 2007.

Estiyanti, Ni Made dan Wirawan Yasa, Gerianta. Pengaruh Faktor Keuangan dan Non Keuangan pada Peringkat Obligasi di Bursa Efek Indonesia, Jurnal Universitas Udayana, 2012.

Fakhruddin dan Sopian Hadianto. 2001. Perangkat dan Model Analisis Investasi

di Pasar Modal. Buku satu. Elex Media Komputindo. Jakarta.

Fama, Eugene F, 1978. The Effect of A Firm Investment dan Financing Decision On the Welefare of Its Security Holder, American Economic Review, Vol. 68.

Ghozali, Imam, 2011. Aplikasi Analisis Multivariate dengan Program IBM SPSS 19, Badan Penerbit Universitas Diponegoro : Semarang.

Helfert, 2003. Technique of Financial Analysis, Boston.

Hidayati, Eva Eko, 2010. Analisis Pengaruh DER, DPR, ROE, dan Size terhadap PBV Perusahaan Manufaktur yang listing di BEI periode 2005-2007, e-Journal UNDIP.

Husnan, Suad, 2003. Dasar-Dasar Teori Portofolio dan Analisis Sekuritas, Edisi Keempat, UPP AMP YKPN : Yogyakarta.

Kasmir. 2010. Pengantar Manajemen Keuangan. Jakarta : Kencana Prenada Media Group.

Mardiyanto, Handono. 2009. Intisari Manajemen Keuangan. Jakarta : Grasindo. 
Noor, Akhmad Syafrudin, 2011. Analisis Faktor-faktor yang Mempengaruhi Kinerja keuangan Perusahaan Telekomunikasi yang Go Publik di Bursa Efek Indonesia, Jurnal Manajemen dan Akuntansi volume 12 nomor 1, April 2011.

Pakpahan, Rosma, 2010. Pengaruh Faktor-faktor Fundamental Perusahaan dan Kebijakan Deviden Terhadap Nilai Perusahaan (Studi Kasus pada Perusahaan Manufaktur di BEI tahun 2003-2007), Jurnal Ekonomi Keuangan, Perbankan dan Akuntansi vol. 2 no. 2 tahun 2010.

Petronila, Thio Anastasia dan Mukhlasin. 2003. Pengaruh Profitabilitas Perusahaan Terhadap Ketepatan Waktu Pelaporan Laporan Keuangan Dengan Opini Audit Sebagai Moderating Variabel. Jurnal Ekonomi dan Bisnis, 1 (Februari). Pp.17-26.

Putra, Tito Perdana, 2007, Pengaruh Kinerja Keuangan dan Beta saham terhadap Price to Book Value (Studi pada Perusahaan Real Estate dan Property yang listed di BEI 2004-2006), e-Journal Undip.

Raharja dan Sari. 2008. Kemampuan Rasio Keuangan dalam Memprediksi Peringkat Obligasi (PT Kasnic Credit Rating). Jurnal Maksi, Vol. 8.

Salvatore, Dominick. 2005. Ekonomi Manajerial dalam Perekonomian Global.

Salemba Empat: Jakarta

Sartono, Agus, 2008. Manajemen Keuangan Teori dan Aplikasi Edisi Empat, BPFE-Yogyakarta, Yogyakarta.

Soliha, E. dan Taswan (2002). Pengaruh Kebijakan Hutang Terhadap Nilai Perusahaan Serta Beberapa Faktor Yang Mempengaruhinya. Jurnal Bisnis dan Ekonomi

Sugiono, 2010. Metode Penelitian Bisnis, Alfabeta : Bandung.

Wardjono, 2010. Analisis Faktor-faktor Yang Mempengaruhi Price to Book Value dan Implikasinya pada Return Saham (Studi Kasus pada Perusahaan Manufaktur yang Terdaftar di BEI), Jurnal Dinamika Keuangan dan Perbankan, Mei 2010 vol. 2 no,1.

Wibowo. 2012. Faktor-faktor penentu tingkat profitabilitas Bank Umum Syariah di Indonesia. Jurnal Ekonomi Islam, 4 (2)

Wirawati, Ni Gusti Putu, 2008. Pengaruh Faktor Fundamental Perusahaan Terhadap Price Book Value Dalam Penilaian Saham Di Bursa Efek Jakarta Dalam Kondisi Krisis Moneter, Buletin Studi Ekonomi Volume 13 No.1 Tahun 2008.

Wulandari, Heni, 2009. Analisis Pengaruh Kinerja Sosial terhadap Nilai Perusahaan di Indonesia dengan Ukuran Perusahaan, Profitabilitas serta Leverage sebagai Control Variable, e-Journal Universitas Sebelas Maret Solo. 